\title{
CIVIL JUSTICE IN SOUTH AFRICA
}

\author{
DANIE VAN LOGGERENBERG,
}

University of Pretoria (South Africa)

DOI: 10.21684/2412-2343-2016-3-4-125-147

The South African adversarial system of civil procedure in the High Court owes its origin to that of England. As with all civil procedural systems, the South African system is not stagnant. Its primary sources, namely Acts of Parliament and rules of court, are constantly amended in an attempt to meet the changing needs of society. Court delay and costinefficient procedural mechanisms, however, contribute to public dismay. The High Court, in the exercise of its inherent power to regulate its process, do so with the purpose of enhancing access to justice. The advantage of the system lies in the fact that it is not cast in stone but could, subject to the Constitution of the Republic of South Africa, 1996, be developed to make it more accessible to the public whilst protecting the public's fundamental rights entrenched in the Constitution and, in this regard, particularly the right to a fair trial embedded in sec. 34 of the Constitution. This contribution gives an overview of the system with reference to the court structure, the judiciary, the process in the High Court and its underlying principles, appeals, class actions and alternative civil dispute resolution mechanisms.

Keywords: court structures; judiciary; civil procedure in the High Court; appeals; class actions; South Africa.

Recommended citation: Danie van Loggerenberg, Civil Justice in South Africa, 3(4) BRICS Law Journal 125-147 (2016).

\section{Table of Contents}

\section{Introduction}

\section{Sources of South African Civil Procedural Law \\ 2. The Court Structure \\ 3. Specialised Courts}


4. The Judiciary

5. The Process

\subsection{The Principles Underlying the Process}

5.2. Proceedings in an Opposed Action

5.3. Proceedings in an Opposed Application

6. Evidence in Civil Proceedings

7. Appeals

8. Class Actions

9. Alternative Civil Dispute Resolution Mechanisms

10. Reform

\section{Introduction}

South African law distinguishes between substantive law and procedural law. Substantive law essentially deals with the contents of a person's rights, obligations and remedies in a given factual situation. Procedural law, including the law of civil procedure, deals with the enforcement of rights, obligations and remedies.

South African law is mainly of Roman-Dutch origin. Its civil procedural law has, however, since the beginning of the $19^{\text {th }}$ Century, assimilated to English methods.'

In this contribution, the focus will eventually be directed at the South African adversarial system of civil procedure in the High Court which owes its origin to that of England, but which has steered an independent course in its development since its implementation by the English in $1828 .^{2}$

Civil procedure is not stagnant. The word "procedure" inherently means "going forward." Viewed as such, civil procedure not only aims at moving forward the dispute between the parties up to the point of its eventual determination by a court, but also aims at reflecting the evolution (i.e. change) of society and its needs. Since all legal systems are closely linked to the historical, cultural, socio-economic and

Hennie Erasmus, The Interaction of Substantive and Procedural Law: The Southern African Experience in Historical and Comparative Perspective, 1 Stellenbosch Law Review 348 (1990).

2 Hennie Erasmus, Historical Foundations of the South African Law of Civil Procedure, 108 The South African Law Journal 265 (1991), where, amongst others, the following is stated: "South African civil procedure 'owes its origin to and is essentially that of England.'The forms of procedure devised under the First and Second Charters of Justice of 1828 and 1834 for the Supreme Court of the Colony of the Cape of Good Hope display the fundamental features characteristic of proceedings at common law, namely, the adversary character of the system and the predominant role of the parties in the conduct of the litigation, the passive and neutral role of the court, and the 'morality, immediacy and publicity of its proceedings."'

3 Wolfgang Bernhardt, Das Zivilprozessrecht (3 $3^{\text {rd }}$ ed., Berlin: De Gruyter, 1968), correctly states that a legal procedure is "als Lebensvorgang betrachtet, ein Verfahren. Daher kommt auch der Name: processor (procedure - vorwärtsschreiten)." 
political milieu in which they have developed and find application, the character of a civil procedural system must necessarily depend upon a variety of factors, juridical and non-juridical, that determine its character. This is especially so in the case of South African civil procedural law which migrated from a superimposition of English procedural law upon Roman-Dutch procedural law to a constitutional dispensation where the Constitution of the Republic of South Africa, 1996 ("the Constitution"), reigns supreme and, accordingly, every rule of civil procedure must be viewed and applied through the prism of the Constitution.

\section{Sources of South African Civil Procedural Law}

South African civil procedural law is not codified. Its main sources are:

(a) The Constitution of the Republic of South Africa, 1996;

(b) The Superior Courts Act 10 of 2013;

(c) The inherent jurisdiction of the Superior Courts derived from sec. 173 of the Constitution;

(d) The Magistrates' Courts Act 32 of 1944;

(e) The Small Claims Court Act 61 of 1984;

(f) Rules of Court; ${ }^{4}$

(g) Practice directives;

(h) The common law (i.e. the Roman-Dutch law to the extent that it has not been repealed or abolished);

(i) Case law.

\section{The Court Structure}

In terms of sec. 166 of the Constitution, the courts in South Africa consist of:

(a) The Constitutional Court;

(b) The Supreme Court of Appeal;

(c) The High Court;

(d) The Magistrates' Courts;

(e) Any other court established or recognised in terms of any Act of Parliament.

The courts are independent and subject only to the Constitution and the law, which they must apply impartially and without fear, favour or prejudice. ${ }^{5}$

No person or organ of state may interfere with the functioning of the courts. ${ }^{6}$

4 These rules consist of the rules of the Constitutional Court, the rules of the Supreme Court of Appeal, the Uniform Rules of Court in force in the various divisions of the High Court and the Magistrates' Courts Rules.

5 Sec. 165(2) of the Constitution.

6 Sec. 165(3) of the Constitution. 
Organs of state, through legislative and other measures, must assist and protect the courts to ensure the independence, impartiality, dignity, accessibility and effectiveness of the courts.?

Sec. 34 of the Constitution guarantees to everyone the right of access to court. It provides:

Everyone has the right to have any dispute that can be resolved by the application of law decided in a fair public hearing before a court or, where appropriate, another independent and impartial tribunal or forum.

\section{Specialised Courts}

The following specialised courts are established or recognised in terms of Acts of Parliament as contemplated in sec. 166 of the Constitution:

4.1. Courts having admiralty jurisdiction: in terms of sec. 2(1) of the Admiralty Jurisdiction Regulation Act, ${ }^{8}$ each division of the High Court of South Africa has jurisdiction (i.e. admiralty jurisdiction) to hear and determine any maritime claim, including in the case of salvage, claims in respect of ships, cargo or goods found on land, irrespective of the place where the claim arose, of the place of registration of the ship concerned or of the residence, domicile or nationality of the ship's owner.

4.2. The Labour Court: in terms of sec. 151 of the Labour Relations Act, ${ }^{9}$ the Labour Court is established as a court of law and equity ${ }^{10}$ with powers equal to that of the High Court." As a general rule, the Labour Court deals exclusively with disputes arising from employment and other labour relations. ${ }^{12}$

4.3. The Labour Appeal Court: in terms of sec. 167 of the Labour Relations Act, ${ }^{13}$ the Labour Appeal Court is established as a court of law and equity ${ }^{14}$ with powers equal to that of the Supreme Court of Appeal. ${ }^{15}$ The Labour Appeal Court is the final court of appeal in respect of all judgments and orders made by the Labour Court. ${ }^{16}$

\footnotetext{
Sec. 165(4) of the Constitution.

8 105 of 1983.

966 of 1995.

10 Sec. 151(1).

11 Sec. 115(2).

12 Sec. 157.

1366 of 1995.

14 Sec. 167(1).

15 Sec. 167(3).

16 Sec. 167(2).
} 
4.4. The Competition Appeal Court: in terms of sec. 36 of the Competition Act, ${ }^{17}$ the Competition Appeal Court is established as a court with a status similar to that of the High Court. ${ }^{18}$ The function of the court is to review any decision of the Competition Tribunal or to consider an appeal arising from the Competition Tribunal. ${ }^{19}$

4.5. The Land Claims Court: in terms of sec. 22 of the Restitution of Land Rights $\mathrm{Act}_{,}{ }^{20}$ the Land Claims Court is established as a court of law ${ }^{21}$ with powers equal, in relation to matters falling within its jurisdiction, to that of the High Court. ${ }^{22}$ The Land Claims Court, to the exclusion of the High Court, has the power, amongst others, to determine:

(a) a right to restitution of any right in land in accordance with the provisions of the Restitution of Land Rights Act; ${ }^{23}$

(b) approve compensation payable in respect of land owned by or in the possession of a private person upon expropriation or acquisition of such land in terms of the Restitution of Land Rights Act;

(c) the person entitled to title to land contemplated in sec. 3 of the Restitution of Land Rights Act;

(d) whether compensation or any other consideration received by any person at the time of any dispossession of a right in land was just and equitable.

4.6. Equality Courts: in terms of sec. 16 of the Promotion of Equality and Prevention of Unfair Discrimination Act, ${ }^{24}$ every division of the High Court is an equality court for the area of its jurisdiction. ${ }^{25}$ Equality Courts deal with inquiries into allegations concerning unfair discrimination, hate speech or harassment. ${ }^{26}$

4.7. The Electoral Court: in terms of sec. 18 of the Electoral Commission Act, ${ }^{27}$ the Electoral Court, with the status of the High Court, is established. ${ }^{28}$ The Electoral

\footnotetext{
1789 of 1998.

18 Sec. 36(1)(a).

19 Sec. 37(1)(a) and (b). The function of the Competition Tribunal is to adjudicate any conduct that is prohibited under the Competition Act and to hear appeals from, or review any decision of, the Competition Commission (sec. 27).

2022 of 1994

21 Sec. 22(1).

22 Sec. 22(2)(a).

$23 \quad 22$ of 1994 .

$24 \quad 4$ of 2000.

25 Sec. 16(1)(a),

26 Sec. 21(1).

$27 \quad 51$ of 1996.

28 Sec. 18.
} 
Court has jurisdiction to review any decision of the Electoral Commission ${ }^{29}$ and to hear and determine an appeal against any decision of the Commission in so far as such decision relates to the interpretation of any law or any other matter for which an appeal is provided by law. ${ }^{30}$

4.8. Children's Courts: in terms of sec. 42 of the Children's Act, ${ }^{31}$ every Magistrate's Court is a Children's Court for its area of jurisdiction..$^{32} \mathrm{~A}$ Children's Court may adjudicate any matter involving, amongst others:

(a) the protection and well-being of a child;

(b) the care of, or contact with a child;

(c) paternity of a child;

(d) support of a child;

(e) maltreatment, abuse, neglect, degradation or exploitation of a child, except criminal prosecutions in that regard;

(f) the temporary safe care of a child;

(g) the adoption of a child, including an inter-country adoption. ${ }^{33}$

4.9. Maintenance Courts: in terms of sec. 3 of the Maintenance Act, ${ }^{34}$ every Magistrate's Court (for a district) is, within its area of jurisdiction, a Maintenance Court. A Maintenance Court has jurisdiction to hold an inquiry into the provision of maintenance, and to make an order against the person legally liable to maintain any other person, to pay maintenance in respect of such latter person. ${ }^{35}$

\section{The Judiciary}

5.1. The Constitutional Court, the Supreme Court of Appeal and the High Court: sec. 174(1) of the Constitution provides that any appropriately qualified woman or man who is a fit and proper person may be appointed as a judicial officer and, further,

29 The Electoral Commission is established by sec. 3 of the Electoral Commission Act 51 of 1996 to strengthen constitutional democracy and promote democratic electoral processes. The functions of the Commission include to -

(i) manage any election;

(ii) ensure that any election is free and fair;

(iii) promote conditions conducive to free and fair elections;

(iv) promote knowledge of sound and democratic electoral processes;

(v) promote voter education.

30 Sec. 20(1)(a) and (b).

3138 of 2005.

32 Sec. 42(1).

33 Sec. 45(1).

3499 of 1998

35 Secs. 10 to 18. 
that any person to be appointed to the Constitutional Court must also be a South African citizen.

5.2. The Labour Court: the Judge President and the Deputy Judge President of the Labour Court must be judges of the High Court $^{36}$ and must have knowledge, experience and expertise in labour law. ${ }^{37}$

A judge of the Labour Court must be a judge of the High Court ${ }^{38}$ or be a person who is a legal practitioner ${ }^{39}$ and have knowledge, experience and expertise in labour law. ${ }^{40}$

5.3. The Labour Appeal Court: the Labour Appeal Court consists of:

(a) the Judge President of the Labour Court, ${ }^{41}$ who, by virtue of the provisions of sec. 153(2) of the Labour Relations Act, ${ }^{42}$ must be a judge of the High Court and must have knowledge, experience and expertise in labour law;

(b) the Deputy Judge President of the Labour Court, ${ }^{43}$ who, by virtue of the provi-sions of sec. 153(2) of the Labour Relations Act, ${ }^{44}$ must be a judge of the High Court and must have knowledge, experience and expertise in labour law;

(c) such number of other judges who are judges of the High Court as may be required for the effective functioning of the Labour Appeal Court, ${ }^{45}$ and each of whom, by virtue of the provisions of sec. 174(1) of the Constitution, must be an appropriately qualified woman or man who is fit and proper to be appointed as a judge of the High Court.

5.4. The Competition Appeal Court: the Judge President of the Competition Appeal Court and each of its judges must be a judge of the High Court, ${ }^{46}$ who, by virtue of the provisions of sec. 174(1) of the Constitution, must be an appropriately qualified woman or man who is fit and proper to be appointed as a judge of the High Court.

5.5. The Land Claims Court: the President of the Land Claims Court and each of its judges:

(a) must be a fit and proper person to be a judge of the Land Claims Court, ${ }^{47}$ and

\footnotetext{
36 Sec. 153(2)(a) of the Labour Relations Act 66 of 1995.

37 Sec. 153(2)(b) of the Labour Relations Act 66 of 1995.

38 Sec. 153(6)(a)(i) of the Labour Relations Act 66 of 1995.

39 Sec. 153(6)(a)(ii) of the Labour Relations Act 66 of 1995.

40 Sec. 153(6)(b) of the Labour Relations Act 66 of 1995.

41 Sec. 168(1)(a) of the Labour Relations Act 66 of 1995.

4266 of 1995 .

43 Sec. 168(1)(b) of the Labour Relations Act 66 of 1995.

4466 of 1995 .

45 Sec. 168(1)(c) of the Labour Relations Act 66 of 1995.

46 Sec. 36(2) of the Competition Act 89 of 1998.

47 Sec. 23(b) of the Restitution of Land Rights Act 22 of 1994.
} 
(b) must be a judge of the High Court or be qualified to be admitted as an advocate or attorney, ${ }^{48}$ and has, for a cumulative period of at least 10 years, practised as an advocate or an attorney or lectured in law at a university; ${ }^{49}$ or

(c) by reason of his or her training and experience, has expertise in the fields of law and land matters relevant to the application of the Restitution of Land Rights Act $^{50}$ and the law of the Republic. ${ }^{51}$

5.6. Equality Courts: only a judge, magistrate or additional magistrate who has completed a training course as a presiding officer of an Equality Court may, subject to the provisions of the Promotion of Equality and Prevention of Unfair Discrimination $\mathrm{Act}^{52}$ be designated as a presiding officer of an Equality Court. ${ }^{53}$

5.7. The Electoral Court: the members of the Electoral Court consist of:

(a) a chairperson, who is a judge of the Supreme Court of Appeal; ${ }^{.4}$ and

(b) two judges of the High Court; ${ }^{.5}$ and

(c) two other members who are South African citizens. ${ }^{56}$

5.8 Children's Courts: the presiding officer of a Children's Court must be a magistrate. ${ }^{57}$ In terms of sec. 10 of the Magistrates' Courts Act, ${ }^{58}$ any appropriately qualified woman or man who is a fit and proper person may be appointed as a magistrate.

5.9 Maintenance Courts: any appropriately qualified woman or man who is a fit and proper person may be appointed as a magistrate.

5.10 In order to fulfil the need for the education and training of judicial officers, a South African judicial education institute was established by the South African Judicial Education Institute $\mathrm{Act}^{59}$ to promote the independence, impartiality, dignity, accessibility and effectiveness of the courts by providing judicial education for judicial officers.

5.11. Traditionally, the function of a judge in South Africa is to express or declare the law and not make law - iudicis est ius dicere sed non dare.$^{60}$ Under sec. 173 of the

48 South Africa has a divided Bar similar to that of England, i.e. attorneys (solicitors) and advocates (barristers).

49 Sec. 23(c)(i) of the Restitution of Land Rights Act 22 of 1994.

5022 of 1994.

51 Sec. 23(c)(ii) of the Restitution of Land Rights Act 22 of 1994.

524 of 2000 .

53 Sec. 16(2) of the Promotion of Equality and Prevention of Unfair Discrimination Act 4 of 2000.

54 Sec. 19(1)(a) of the Electoral Commission Act 51 of 1996.

55 Id.

56 Sec. 19(1)(b) of the Electoral Commission Act 51 of 1996.

57 Sec. 42(2) of the Children's Act 38 of 2005.

5832 of 1944.

$59 \quad 14$ of 2008 .

60 Lucas C. Steyn, Die Uitleg van Wette (Interpretation of Statutes) 1 (5 ${ }^{\text {th }}$ ed., Cape Town: Juta, 1981). 
Constitution, the Constitutional Court, Supreme Court of Appeal and High Court, however, have the inherent power to develop the common law, ${ }^{61}$ taking into account the interests of justice. In addition, sec. 172 of the Constitution provides as follows in respect of the powers of the Superior Courts in constitutional matters:

(1) When deciding a constitutional matter within its power, a court -

(a) must declare that any law or conduct that is inconsistent with the Constitution is invalid to the extent of its inconsistency; and

(b) may make any order that is just and equitable, including -

(i) an order limiting the retrospective effect of the declaration of invalidity; and

(ii) an order suspending the declaration of invalidity for any period and on any conditions, to allow the competent authority to correct the defect.

(2)(a)The Supreme Court of Appeal, the High Court of South Africa or a court of similar status may make an order concerning the constitutional validity of an Act of Parliament, a provincial Act or any conduct of the President, but an order of constitutional invalidity has no force unless it is confirmed by the Constitutional Court.

(b) A court which makes an order of constitutional invalidity may grant a temporary interdict or other temporary relief to a party, or may adjourn the proceedings, pending a decision of the Constitutional Court on the validity of that Act or conduct.

(c) National legislation must provide for the referral of an order of constitutional invalidity to the Constitutional Court.

(d) Any person or organ of state with a sufficient interest may appeal, or apply, directly to the Constitutional Court to confirm or vary an order of constitutional invalidity by a court in terms of this subsection.

\section{The Process}

Under this heading the following will be briefly discussed:

(a) The principles underlying the process;

(b) A typical opposed action in the High Court;

(c) A typical opposed application in the High Court;

(d) Evidence in civil proceedings;

(e) Appeals;

(f) Class actions;

(g) Alternative civil dispute resolution mechanisms.

\footnotetext{
61 The South African common (i.e. substantive) law is of Roman-Dutch origin.
} 


\subsection{The Principles Underlying the Process ${ }^{62}$}

The audi alteram partem principle prevails, in other words, throughout the process the parties must be afforded an equal opportunity to present their respective cases to each other and to the court. This entails that each party is entitled to be informed of the other party's case so as, eventually, not to be taken by surprise at the hearing of the case.

Each party is in control of its case, in other words, the decision to institute or defend a case, and to determine the scope of the disputes, rest with the parties. Each party also decides on the evidentiary material to be presented to court in support of its case.

The hearing of the case must, as a general rule, take place in public.

In action proceedings, the principle of orality prevails. This means that at the hearing of the case, the parties and their witnesses give oral evidence.

The judge presiding over a case may not enter the arena and should be impartial and unbiased.

The judge is under an obligation to give a reason and legally motivated judgment within a reasonable time. ${ }^{63}$

The following principles apply in respect of the rules of court:

(a) Formalism in the application of the rules of court is not encouraged by the courts; ${ }^{64}$

(b) The object of the rules is to secure the inexpensive and expeditious completion of litigation before the courts: they are not an end in themselves; ${ }_{i}^{.55}$

(c) The rules should be interpreted and applied in a spirit which will facilitate the work of the courts and enable litigants to resolve their disputes in as speedy and inexpensive a manner as possible, ${ }^{66}$

(d) The rules exist for the court, not the court for the rules;

62 See, in general, Wouter le R. de Vos, Civil Procedural Law and the Constitution of 1996: An Appraisal of Procedural Guarantees in Civil Proceedings, 3 Journal of South African Law 444 (1997); Estelle Hurter, Seeking Truth or Seeking Justice: Reflections on the Changing Face of the Adversarial Process of Civil Litigation, 2 Journal of South African Law 240 (2007).

63 See, for example, Strategic Liquor Services v. Mvumbi NO 2010 (2) SA 92 (CC) and Exdev (Pty) Ltd v. Pekudei Investments (Pty) Ltd 2011 (2) SA 282 (SCA).

64 Trans-African Insurance Co Ltd v. Maluleka 1956 (2) SA 273 (A) at 277A-B; Maharaj v. Barclays National Bank Ltd 1976 (1) SA 418 (A) at 423E; Federated Trust Ltd v. Botha 1978 (3) SA 645 (A) at 654C; Rabie v. De Wit 2013 (5) SA 219 (WCC) at 222E-223A.

65 Hudson v. Hudson 1927 AD 259 at 267; Federated Trust Ltd v. Botha, supra, at 654C-E; Eke v. Parsons 2016 (3) SA 37 (CC) at para. [40].

66 Ncoweni v. Bezuidenhout 1927 CPD 130

67 Republikeinse Publikasies (Edms) Bpk v. Afrikaanse Pers Publikasies (Edms) Bpk 1972 (1) SA 773 (A) at 783A-B; Standard Bank of South Africa Ltd v. Dawood 2012 (6) SA 151 (WCC) at 159E; Mukaddam v. Pioneer Foods (Pty) Ltd 2013 (5) SA 89 (CC) at para. [32]; Eke v. Parsons, supra, at paras. [39]-[40]. 
(e) The court has inherent power to read the rules applicable to procedure in a manner which would enable practical justice to be administered and a matter to be handled along practical lines; ${ }^{68}$

(f) The rules are devised for the purpose of administering justice and not of hampering it - the primary purpose of the rules is the attainment of justice, ${ }^{69}$

(g) Technical objections to less than perfect procedural steps should not be permitted, in the absence of substantial prejudice, to interfere with the expeditious and inexpensive decision of cases on their merits. ${ }^{70}$

\subsection{Proceedings in an Opposed Action}

In a typical action in the High Court, which commences with the issue and delivery of a summons, ${ }^{71}$ it is for the parties to take all the necessary steps to initiate the action and to prepare the case for trial, while the function of the judge is merely to consider requests for interim relief by the parties. Even at the trial, the parties play a leading role. They determine what evidence is to be presented to the court and they conduct their examination (questioning) of the witnesses. The function of the court is to see to it that the proceedings are conducted according to the prescribed procedure and to deliver a judgment at the conclusion of the trial.

The pre-trial phase is characterized by the exchange of pleadings between the parties and certain procedures, such as discovery, whereby they prepare themselves for the trial. The trial, in turn, is a continuous process which is characterized by the immediate (direct) and, mainly, oral presentation of evidence. On this occasion the parties present all the evidentiary material at their disposal to establish their respective cases, whereafter the judge gives a judgment based upon such material. ${ }^{72}$ The proceedings are dominated by the advocates appearing on behalf of the parties, while the function of the judge is merely to ensure that the advocates keep to the "rules of the game." After both parties have closed their cases they get the opportunity, in turn, to present their arguments to the judge. The purpose of these arguments is twofold: first,

68

69 Mukaddam v. Pioneer Foods (Pty) Ltd, supra, at para. [32].

70

71 by, in the event of an opposed motion, the respective parties' affidavits (i.e. founding, answering and replying affidavits).

72 Judges in South Africa do not have the power to search for the truth on their own motion, but is constrained to base their findings on the evidence presented to them by the parties. It follows that South African judges can hardly aspire to find the objective truth. They must necessarily contend themselves with the formal truth or, at best, a combination of the objective and formal truth (Wouter le R. de Vos \& Daniel E. van Loggerenberg, Activism of the Judge in South Africa, 4 Journal of South African Law 592, 598 (1991)). 
to persuade the judge to make a factual finding in favour of the party concerned and, secondly, to make submissions in regard to the relevant legal principles, substantiated by legal authority. The advocates play a leading role in presenting their arguments, but the court does not hesitate to put questions to them, to raise problematical points and to draw their attention to any authority that they have overlooked. Although it is for the advocates to appraise the judge of the legal authorities upon which they rely in support of their submissions, the principle of "judicial unpreparedness" is not very strictly adhered to. The result is that "the court has a duty to ensure that it ascertains the correct legal position regarding any points of law actually raised and argued by the parties."73 The court, however, has no power or duty to decide a civil dispute on the basis of what it believes to be the "truly relevant" legal issues arising from the facts placed before it. This is the prerogative of the parties.

Once the advocates have concluded their arguments, the court may proceed to deliver an ex tempore oral judgment, but it happens more often that the judge reserves judgment for consideration and delivers it at a later stage in written form. The judgment must be recorded and it has become an established practice that courts motivate their judgments regarding both the facts and the law. ${ }^{74}$

\subsection{Proceedings in an Opposed Application}

A typical opposed application will commence with a notice of motion supported by a founding affidavit. In the notice of motion:

(a) the division of the High Court in which the application is brought will be indicated;

(b) the parties to the application will be identified;

(c) the order sought by the applicant (i.e. the relief claimed) will be set out;

(d) the time periods within which the respondent party has to give notice of intention to oppose the application and to file an answering affidavit will be stated.

In the founding affidavit the facts upon which the applicant relies must be set out simply, clearly and in chronological sequence, without argumentative matter. The statement of facts must at least contain the following information:

(a) the applicant's right to apply, that is, the applicant's locus standi in iudicio;

(b) the facts indicating that the court has jurisdiction;

(c) the course of action on which the applicant relies;

(d) the evidence in support of the application.

73 Lawrence G. Baxter, Civil Litigation and Jura Novit Curia, 96 South African Law Journal 531, 536 (1979).

74 This practice is based upon considerations of fairness to the parties and it also facilitates the process of appeal.

75 See, in general, Daniel E. van Loggerenberg, Erasmus Superior Court Practice. Vol. 2 ( $2^{\text {nd }}$ ed., Cape Town: Juta, 2015). 
The opposing papers in an opposed application will, generally, consist of:

(a) a notice to oppose;

(b) an answering affidavit.

In response to the answering affidavit, the applicant is entitled to file a replying affidavit. As a general rule, all the necessary allegations upon which the applicant relies must appear in the founding affidavit, as the applicant will not be allowed to supplement the founding affidavit by adducing supporting facts in the replying affidavit.

There are normally only the abovementioned three sets of affidavits in application proceedings. The court will, however, in the exercise of its discretion permit the filing of further affidavits against the backdrop of the fundamental consideration that a case should be adjudicated upon all the facts relevant to the issues in dispute. A fourth set of affidavits will only in exceptional circumstances (e.g. where something unexpected or new emerged from the applicant's replying affidavit) be allowed.

Legal argument, based on the facts contained in the affidavits, will orally be presented by the legal representatives to the court at the hearing of the opposed application although it is standard practice that written heads of argument be filed prior to the hearing of the application.

\section{Evidence in Civil Proceedings ${ }^{76}$}

The South African law of evidence is not based on Roman-Dutch authority. The rules of evidence are found in Acts of Parliament and, where these are silent on a specific issue, the English Law of evidence which was in force in South Africa on May 30, 1961 serves as the common law. There exists a substantial body of local case law on evidence which, as already stated above, are binding in terms of the doctrine of judicial precedent.

Sec. 35(5) of the Constitution provides that evidence obtained in a manner that violates any right in the Bill of Rights (which is contained in the Constitution) must be excluded if the admission of that evidence would render the trial unfair or otherwise be detrimental to the administration of justice.

The degree of proof required for a case to be decided in favour of the party who asserts is known as "proof on a balance of probabilities."

In a typical opposed action, after the close of pleadings, the action proceeds through the next stage where the emphasis is on discovery of documents, the procedural requirements in regard to expert evidence, the steps to be taken by the parties in order to obtain statements of witnesses in support of their respective

\footnotetext{
76 See, in general, David T. Zeffertt and Andrew P. Paizes, The South African Law of Evidence (2 ${ }^{\text {nd }}$ ed., Durban: LexisNexis, 2009).

77 Ocean Accident and Guarantee Corporation Ltd v. Koch 1963 (4) SA 147 (A).
} 
cases ${ }^{78}$ and steps to be taken in order to ensure the presence of witnesses at the trial. Traditionally the preparatory stage is also dominated by the parties. It is for the parties to take the initiative in regard to all these procedures. ${ }^{79}$ As a general rule the court exercises no control over the development of this phase of the proceedings, except in so far as it may be called upon to resolve a dispute relating to one or the other of the procedures involved.

The trial is a "single continuous drama" where the parties present all the evidentiary material at their disposal to establish their respective cases. As a general rule, evidence is given orally and each witness is subject to cross-examination by the legal representative of the other party, whereafter the judge gives a judgment based upon such material. During the trial the judge is constrained to adopt a passive and neutral attitude lest it be seen that the judge "descends into the arena and be liable to have his vision clouded by the dust of the conflict. ${ }^{180}$ The judge may, however, put questions to a witness in order to clarify obscure points and it is the judge's duty to see to it that the legal representatives appearing on behalf of the parties behave themselves seemly and comply with the prescribed procedure. The judge is not allowed to go beyond this, by, for example, putting questions to witnesses in the form of cross-examination or to call witnesses not called by the parties out of his own accord.

Over the years the "powers" of the parties in taking and presenting evidence ${ }^{81}$ have indirectly been evolved by the Legislature and the courts. Examples of such evolution include the following:

(a) Whenever a commercial bank claims payment of money said to be owing to it by a customer who enjoys overdraft facilities on a current account which fluctuates, possibly from day to day, it must needs rely on its books of account and other records of transactions in order to establish the amount due to it by the customer or by a person who bound himself as surety and co-principal debtor. To prove every one of the many entries in the books, which may have been made from time to time by a large number of different employees, might for obvious reasons sometimes be extremely difficult. It has, therefore, become customary for commercial banks to

78 The witness statements are privileged and are not disclosed to the court or the other party/parties.

79 See, in general, Hurter 2007. At 242 Hurter, inter alia, states:

"The parties interview witnesses (including experts) and alone decide which of these will be called upon to testify and in what order. The preparation and presentation of the case before and at the trial are thus in the hands of the parties."

At 243 Hurter states:

"To summarise: under the adversarial system it is the parties who dictate at all stages the form, content and pace of proceedings."

80 Per Lord Greene in Yuill v. Yuill 1945 All ER 183 (CA); and see Hamman v. Moolman 1968 (4) SA 340 (A) at 344E-G.

81 The South African law of evidence is based on that of England as at May 30, 1961. See, in this regard, Zeffertt \& Paizes 2009, at13 et seq. 
include in its agreements with customers and sureties, a clause to the effect that a certificate purportedly signed by any manager of the bank would constitute prima facie evidence of the nature of the debt and of the amount due by the debtor to the bank and, further, that such certificate would on its mere production in a court constitute such evidence. In Senekal v. Trust Bank of Africa $L t d^{82}$ the Appellate Division (now the Supreme Court of Appeal) approved of the use of such certificates. ${ }^{83}$

(b) The Electronic Communications and Transactions Act, ${ }^{84}$ inter alia, provides ${ }^{85}$ that a data message ${ }^{86}$ made by a person in the ordinary course of business, or a copy or printout of or an extract from such data message certified to be correct by an officer in the service of such person, is on its mere production in any civil proceedings admissible in evidence against any person and rebuttable proof of the facts contained in such record, copy, printout or extract. Pursuant to this provision commercial banks are, for example, empowered to prove bank statements by means of its mere production in civil proceedings.

(c) Sec. 3 of the Law of Evidence Amendment Act ${ }^{87}$ empowers the parties to take and present hearsay evidence under certain conditions. It has revolutionised the approach to hearsay evidence. ${ }^{88} \mathrm{Sec} .3$ reads as follows:

3. (1) Subject to the provisions of any other law, hearsay evidence shall not be admitted as evidence at criminal or civil proceedings, unless -

(a) each party against whom the evidence is to be adduced agrees to the admission thereof as evidence at such proceedings;

(b) the person upon whose credibility the probative value of such evidence depends, himself testifies at such proceedings; or

(c) the court, having regard to -

(i) the nature of the proceedings;

(ii) the nature of the evidence;

(iii) the purpose for which the evidence is tendered;

821978 (3) SA $375($ A).

83 It is upon the debtor to rebut the prima facie evidence. If the prima facie evidence remains unrebutted at the close of the case, it becomes sufficient proof of the facts set out in the certificate.

The Act came into force on August 30, 2002. For a more comprehensive treatment of the law, see Julien Hofman, South Africa in Electronic Evidence: Disclosure, Discovery and Admissibility (S. Mason et al., eds., London: LexisNexis, 2007).

In sec. 15 thereof.

86 any form" and a "data message" as meaning "data generated, sent, received or stored by electronic means and includes - (a) voice, where the voice is used in an automated transaction; and (b) a stored record."

$87 \quad 45$ of 1988.

88 See, in general, Zeffertt \& Paizes 2009, at 389 et seq. 
(iv) the probative value of the evidence;

(v) the reason why the evidence is not given by the person upon whose credibility the probative value of such evidence depends;

(vi) any prejudice to a party which the admission of such evidence might entail; and

(vii) any other factor which should in the opinion of the court be taken into account,

is of the opinion that such evidence should be admitted in the interests of justice.

(2) The provisions of subsection (1) shall not render admissible any evidence which is inadmissible on any ground other than that such evidence is hearsay evidence.

(3) Hearsay evidence may be provisionally admitted in terms of subsection (1)(b) if the court is informed that the person upon whose credibility the probative value of such evidence depends, will himself testify in such proceedings: Provided that if such person does not later testify in such proceedings, the hearsay evidence shall be left out of account unless the hearsay evidence is admitted in terms of paragraph (a) of subsection (1) or is admitted by the court in terms of paragraph (c) of that subsection.

(4) For the purposes of this section -

"hearsay evidence" means evidence, whether oral or in writing, the probative value of which depends upon the credibility of any person other than the person giving such evidence;

"party" means the accused or party against whom hearsay evidence is to be adduced, including the prosecution.

(d) Inspections in loco are principally intended to enable the court to follow and apply the evidence, but may also include some real evidence that is led in the trial. In Kruger v. Ludick ${ }^{89}$ the practice in these matters was described as follows:

It is important, when an inspection in loco is made, that the record should disclose the nature of the observations of the court. That may be done by means of a statement framed by the court and intimated to the parties who should be given an opportunity of agreeing with it or challenging it, and if, if they wish, of leading evidence to correct it. Another method, which is sometimes convenient, is for a court to obtain the necessary statement from a witness, who is called, or recalled, after the inspection has been made. In such a case, the party should be allowed to examine the witness in the usual way.

$89 \quad 1947$ (3) SA 23 (A) at 31. 
In the premises, there is currently no talk in South Africa of "going forward" as far as the powers of the judge regarding taking of evidence are concerned. The parties remain in control of the taking of evidence, and distinctly so.

\section{Appeals}

The Superior Courts Act ${ }^{90}$ provides for a system of appeals in the Superior Courts. Sec. 16(1) of the Act caters for the following situations:

(a) an appeal against any decision of a single judge of a division of the High Court, sitting as a court of first instance, upon leave having been granted, either to the Supreme Court of Appeal or to a full court of that division (sec. 16(1)(a)(i));

(b) an appeal against any decision of more than one judge of a division of the High Court, sitting as a court of first instance, to the Supreme Court of Appeal (sec. 16(1)(a)(ii));

(c) an appeal against any decision of a division of the High Court on appeal to it, to the Supreme Court of Appeal (sec. 16(1)(b));

(d) an appeal against any decision of a court of a status similar to the High Court, to the Supreme Court of Appeal (sec. 16(1)(c)).

In each of the aforesaid situations an appeal lies only upon leave to appeal having been granted by the court of first instance or the Supreme Court of Appeal, as the case may be.

In accordance with the general rule laid down in Zweni v. Minister of Law and Order of the Republic of South Africa, a "decision" contemplated in sec. 16(1) of the Act has three attributes: ${ }^{22}$

(i) it must be final in effect and not susceptible to alteration by the court of first instance;

(ii) it must be definitive of the right of the parties, i.e. it must grant definite and distinct relief; and

(iii) it must have the effect of disposing of at least a substantial portion of the relief claimed in the main proceedings. ${ }^{93}$

In terms of sec. 17(1) of the Act, leave to appeal may only be given where the judge or the judges concerned are of the opinion that -

(a) the appeal would have a reasonable prospect of success (sec. 17(1)(a)(i));

(b) there is some other compelling reason why the appeal should be heard, including conflicting judgments on the matter under consideration (sec. 17(1)(a)(ii));

9010 of 2013

911993 (1) SA 523 (A) at 532I-533B.

92 Cf. South African Broadcasting Corporation Soc Ltd v. Democratic Alliance 2016 (2) SA 522 (SCA) at 557I-558D.

93 See also Van Streepen \& Germs (Pty) Ltd v. Transvaal Provincial Administration 1987 (4) SA 569 (A) at 586I-587B; Marsay v. Dilley 1992 (3) SA 944 (A) at 962C-F. 
(c) the decision sought on appeal will have a practical effect or result (in other words, if the issues are of such a nature that the decision sought to be appealed against will have no practical effect or result, leave to appeal will be refused) (sec. $17(1)(b))$;

(d) where the decision sought to be appealed does not dispose of all the issues in the case, the appeal would lead to a just and prompt resolution of the real issues between the parties (sec. 17(1)(c)).

An appeal to the Constitutional Court in a matter other than a constitutional matter is subject to leave to appeal by the Constitutional Court on the grounds that the matter raises an arguable point of law of general public importance which ought to be considered by the Constitutional Court. ${ }^{94}$

The operation and execution of a decision which is the subject of an application for leave to appeal or an appeal, is suspended pending the decision of the application or appeal..$^{95}$ A court may, however, on application by a party who proves on a balance of probabilities that such parties will suffer irreparable harm if the operation and execution of a decision are not suspended (and that the other party will not suffer irreparable harm), order that a decision which is the subject of an application for leave to appeal or of an appeal be executed..$^{96}$ If a court so orders, the aggrieved party has an automatic right of appeal to the highest court, which court must hear such an appeal as a matter of extreme urgency. ${ }^{97}$

\section{Class Actions}

Anyone listed in sec. 38 of the Constitution has the right to approach a competent court, alleging that a right in the Bill of Rights has been infringed or threatened, and the court may grant appropriate relief, including a declaration of rights. The persons who may approach a court are -

(a) anyone acting in their own interest;

(b) anyone acting on behalf of another person who cannot act in their own name;

(c) anyone acting as a member of, or in the interest of, a group or class of persons;

(d) anyone acting in the public interest; and

(e) an association acting in the interest of its members.

Neither the common law nor legislation made provision for a class action in nonconstitutional claims not directly based on the alleged infringement of a fundamental right in the Bill of Rights.

\footnotetext{
94 Sec. 167(3)(b)(ii) of the Constitution.

95 Sec. 18(1) of the Superior Courts Act 10 of 2013.

96 Sec. 18(1), (2) and (3) of the Superior Courts Act 10 of 2013.

97 Sec. 18(4) of the Superior Courts Act 10 of 2013.
} 
In Children's Resource Centre Trust v. Pioneer Food (Pty) Ltd ${ }^{98}$ the Supreme Court of Appeal developed the common law to allow for the use of a class action in nonconstitutional claims.9

The reasoning that led the Supreme Court of Appeal to this development was that it would be irrational to allow class actions for constitutional matters and not non-constitutional claims, because of the similarities involved.

The Supreme Court of Appeal laid down the following requirements for a class action involving non-constitutional rights:

(a) Certification ${ }^{100}$.

The party seeking to represent a class must apply to a court for it to certify the action as a class action. Thereafter it may issue summons. The court faced with the application need consider and be satisfied of the presence of the following factors, before certifying the action -

(i) the existence of a class identifiable by objective criteria;

(ii) a cause of action raising a triable issue;

(iii) that the right to relief depends on the determination of issues of fact, or law, or both, common to all members of the class;

(iv) that the relief sought, or damages claimed, flow from the cause of action and are ascertainable and capable of determination;

(v) that where the claim is for damages, there is an appropriate procedure for allocating the damages to the class members;

(vi) that the proposed representative is suitable to conduct the action and to represent the class;

(vii) whether, given the composition of the class and the nature of the proposed action, a class action is the most appropriate means of determining the claims of class members.

(b) Class definition ${ }^{101}$.

The applicant for certification must define the class with enough precision for a class member to be identified at all stages of the proceedings.

(c) A cause of action that raises a triable issue ${ }^{102}$.

The applicant must show a cause of action with a basis in law and the evidence. That is, the claim must be legally tenable, and there needs to be evidence of a prima facie case.

98

99 Constitution, which provides that the Constitutional Court, the Supreme Court of Appeal and the
High Court each has the inherent power to protect and regulate their own process and to develop
the common law, taking into account the interests of justice.

101 At 229E-H and 213F-G.

102 At 232A-E and 233B-236B. 
(d) The procedure to be adopted in an application for certification ${ }^{103}$.

The application must be accompanied by draft particulars of claim setting out the cause of action, the class, and the relief sought. The affidavits need to set out the evidence available to support the cause, as well as evidence it is anticipated will become available, and the way it will be procured.

(e) Common issues of fact or law $w^{104}$.

There must be issues of fact, or law, or fact and law, common to all members of the class, and which are determinable in one action.

(f) The representative plaintiff and his lawyers ${ }^{105}$.

The representative plaintiff may be a member of the class or a person acting in its interest. This applies both to class actions based on a constitutional right and to other class actions. The representative's interests cannot conflict with those of the class members; and he or she must also have the capacity to properly conduct the litigation. The capacity requirement entails the ability to procure evidence, to finance the litigation and to access lawyers. The payment arrangement with the lawyers need also be disclosed, and cannot give rise to a conflict of interest of the lawyers and the class members.

On the same day that the Supreme Court of Appeal delivered judgment in the Children's Resource Centre case, it delivered judgment in a related matter, Mukkaddam v. Pioneer Food (Pty) $L t d^{106}$ involving a bread distributor seeking permission to institute a class action against the bread producers who allegedly made themselves guilty of unlawful, anti-competitive, price-fixing. The reasoning in the Children's Resource Centre and Mukkaddam cases was materially synchronic. Because the applicant in the Mukkaddam case, however, sought to pursue an "opt-in" class action in terms of which claimants who join the class as a matter of individual choice, the Supreme Court of Appeal held that the circumstances of the case did not warrant a class action since joinder under rule 10 of the High Court's rules of court allows multiple plaintiffs to join in a single action. The Supreme Court of Appeal recorded that the only advantage in favour of a class action which was advanced on the applicant's behalf was that he would be insulated against personal liability for costs. The court did not consider this to be adequate to move it to authorize the institution of a class action where access to court may equally be achieved by means of a joint action such as that contemplated by rule 10 .

The Mukkaddam case went on appeal to the Constitutional Court sub nomine Mukaddam v. Pioneer Foods (Pty) Ltd. ${ }^{107}$ The Constitutional Court held that: ${ }^{108}$

\footnotetext{
103 At 236A-F.

104 At 236F-237D.

105 At 237D-238D.

1062013 (2) SA 254 (SCA).

1072013 (5) SA 89 (CC).

108 At 99D-101C
} 
(a) pursuant to sec. 173 of the Constitution, which alludes to the "interests of justice," the standard which must be applied in adjudicating applications for certification to institute class actions, is the "interests of justice";

(b) the requirements laid down by the Supreme Court of Appeal in the Children's Resource Centre case must serve as factors to be taken into account in determining where the interests of justice lie in a particular case. They must not be treated as conditions precedent or jurisdictional facts which must be present before an application for certification may succeed. The absence of one or another requirement must not oblige a court to refuse certification where the interests of justice demand otherwise;

(c) none of the abovementioned factors is decisive of the issue;

(d) in the light of sec. 34, read with sec. 38 of the Constitution, there can be no justification for elevating requirements for certification to the rigid level of prerequisites for the exercise of the power confirmed, without restrictions. In this regard, sec. 173 of the Constitution does not limit the exercise of the power nor does it lay down any condition, except that what is done must be in the interests of justice. Compelling reasons would therefore be necessary for introducing inflexible requirements;

(e) courts must embrace class actions as one of the tools available to litigants for placing disputes before them. However, it is appropriate that the courts should retain control over class actions. Permitting a class action in some cases may, as the Supreme Court of Appeal has observed in the Mukkaddam case, be oppressive and as a result inconsistent with the interests of justice. It is therefore necessary for courts to be able to keep out of the justice system class actions which hinder, instead of advance, the interests of justice. In this way prior certification will serve as an instrument of justice rather than a barrier to it;

(f) what is said about certification that must be obtained before instituting a class action of a non-constitutional nature, must not be construed to apply to class actions in which the enforcement of rights entrenched in the Bill of Rights is sought against the state. Proceedings against the state assume a public character which necessarily widens the reach of orders issued to cover persons who were not privy to a particular litigation. In these circumstances, it is neither prudent nor necessary to pronounce on whether prior certification must be obtained for class actions instituted in terms of sec. 38 of the Constitution, without interpreting the section. That aspect therefore lives for another day.

Class actions put new demands on South African judges and courts to be multiskilled and multitasked in order to guarantee multi-access to large numbers of litigants who are joined in such actions. To this extent, and in order to guarantee access to court to the individuals forming part of a class action, judges will need the necessary expertise (through experience and training) to ensure that they remain multi-skilled and wellequipped to perform the multi-tasks that are inherently part of class actions. 


\section{Alternative Civil Dispute Resolution Mechanisms}

South African law provides for three forms of alternative civil dispute resolution mechanisms, namely:

(a) negotiation;

(b) mediation;

(c) arbitration. ${ }^{109}$

It is a new trend to provide in legislation pertaining to commerce to provide for alternative dispute resolution mechanisms and alternative forums such as tribunals to deal with disputes arising from such legislation. ${ }^{110}$

\section{Reform}

Under the new socio-political and economic dispensation that came about in South Africa after the fall of apartheid in 1994, South African civil procedural law is constantly under pressure to change in order to meet the changing needs of society. The greatest challenge facing South African lawmakers is that of making litigation less costly and the courts more accessible to a far greater number of people. More and more South Africans are dismayed by, amongst others, court delay and costinefficient procedural rules. Their dismay is fuelled by high costs of litigation, late settlements, restricted resources and the like. The advantage, however, of the South African civil procedural system is that it is not cast in stone but could, subject to the Constitution, be developed to make it more accessible to the public whilst protecting the public's fundamental rights entrenched in the Constitution and, in particular, the right to a fair trial embedded in sec. 34 thereof.

\section{References}

Baxter L.G. Civil Litigation and Jura Novit Curia, 96 South African Law Journal (1979). Bernhardt W. Das Zivilprozessrecht (3 ${ }^{\text {rd }}$ ed., Berlin: De Gruyter, 1968).

De Vos W. le R. \& Van Loggerenberg D.E. Activism of the Judge in South Africa, 4 Journal of South African Law (1991).

De Vos W. le R. Civil Procedural Law and the Constitution of 1996: An Appraisal of Procedural Guarantees in Civil Proceedings, 3 Journal of South African Law 444 (1997).

In terms of the Arbitration Act 42 of 1965. See also John A. Faris, The Procedural Flexibility of Arbitration as an Adjudicative Alternative Dispute Resolution Process, 41 De Jure 504 (2008). Arbitration proceedings can be conducted by a formal national or international arbitration body such as, for example, the national body known as the Arbitration Foundation of South Africa.

110 See, for example, ch. 7, pts. C and F of the Companies Act 71 of 2008; ch. 7 of the National Credit Act 34 of 2005; secs. 70 and 75 of the Consumer Protection Act 68 of 2008. 
Erasmus H.J. Historical Foundations of the South African Law of Civil Procedure, 108 The South African Law Journal (1991).

Erasmus H.J. The Interaction of Substantive and Procedural Law: The Southern African Experience in Historical and Comparative Perspective, 1 Stellenbosch Law Review (1990).

Faris J.A. The Procedural Flexibility of Arbitration as an Adjudicative Alternative Dispute Resolution Process, 41 De Jure (2008).

Hofman J. South Africa in Electronic Evidence:Disclosure, Discovery and Admissibility (S. Mason et al., eds., London: LexisNexis, 2007).

Hurter E. Seeking Truth or Seeking Justice: Reflections on the Changing Face of the Adversarial Process of Civil Litigation, 2 Journal of South African Law 240 (2007).

Steyn L.C. Die Uitleg van Wette (Interpretation of Statutes) $\left(5^{\text {th }}\right.$ ed., Cape Town: Juta, 1981).

Van Loggerenberg D.E. Erasmus Superior Court Practice. Vol. 2 ( $2^{\text {nd }}$ ed., Cape Town: Juta, 2015).

Zeffertt D.T. \& Paizes A.P. The South African Law of Evidence $\left(2^{\text {nd }}\right.$ ed., Durban: LexisNexis, 2009).

\section{Information about the author}

Danie van Loggerenberg (Pretoria, South Africa) - Member of the Pretoria Bar, Formerly Professor of Law, University of Port Elizabeth, Extraordinary Professor of Law, University of Pretoria (Private Bag X08, Brooklyn Square, Pretoria, 0075, South Africa; e-mail: danievl@webmail.co.za). 